\title{
Sivistystyön vapaus sisältää myös vastuun
}

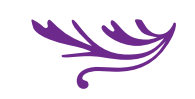

KOULUTUKSEN JÄRJESTÄMINEN on muuttuvassa yhteiskunnassa haasteellinen ja ammattitaitoa vaativa tehtävä. Tarjonnan kirjo on laaja ja resurssit ovat rajalliset. Haasteet ovat samankaltaisia kaikissa koulutusmuodoissa - siksi koulutusmaailma on elänyt ja elää edelleenkin muutosten aikaa.

Yhteistyöstä on muodostunut mitä tärkein tapa toimia yhteiskunnassa. Tämä näkyy myös siten, että vapaan sivistystyön lakiin lisättiin yhteistyövelvoite lakimuutoksella vuonna 2009. Kuulostaa hyvältä sanoa, että teemme yhteistyötä, mutta tehdäänkö sitä yhteistyötä oikeasti, vai onko meillä vain kirjallinen sopimus, mutta mitään ei käytännössä tapahdu?

Yhteistyön onnistumisen kannalta on tärkeää varmistaa, että kaikilla osapuolilla on mahdollisuus saada lisäarvoa yhdessä toimimisesta. Nyky-yhteiskunnassa motivoivaksi tekijäksi on usein muodostunut tiukka taloudellinen tilanne tai opiskelijarekrytoinnin vaikeudet. Myös koulutuksen laadulliset tekijät tai koulutuksen arvostuksen lisääminen voivat kannustaa yhteistyöhön.

Nämä asiat ovat kaikille oppilaitoksille yhteisiä. Sen takia moni on nähnyt, että niihin on parempi etsiä ratkaisuja yhdessä sen sijaan, että yrittää toimia itsekseen. Yhteistyö palkitsee, kun osapuolet kokevat saaneensa sen avulla uutta voimaa toimintaansa.

\section{YHDISTYMISTÄ PITÄISI ENNAKOIDA}

Yhteistyön seuraava vaihe voi joskus johtaa organisaatioiden yhdistymiseen. Yhdistymisen tarpeet lähtevät yleensä koulutuksen ylläpitäjän taloudellisista haasteista ja tarpeesta pystyä käyttämään resursseja ja erityisosaamista tehokkaammin.

Usein kuitenkin odotetaan liian kauan. Yhdisty- mismahdollisuuksia ryhdytään miettimään vasta sitten, kun sisäinen tilanne on muodostunut jo todella vaikeaksi. Hyvän lopputuloksen saamiseksi vaihtoehtoa kannattaisi ennakoida ja ajatella yhdistymistä kehitysmahdollisuutena eikä pelastuskeinona tiukkaan taloudelliseen tilanteeseen.

Lopputuloksena voi syntyä vahva organisaatio, jolla on enemmän osaamista ja usein moninaisempaa toimintaa kuin alkuperäisissä organisaatioissa. Päällekkäisyydet ja sisäinen kilpailu voidaan karsia ja resurssit käyttää tehokkaammin.

Yhteiskuntamme huono taloudellinen tilanne ei ole ohimenevä ilmiö, vaan talouden niukkuus näyttää jatkuvan tulevinakin vuosina. Siksi on erityisen tärkeää miettiä yhdessä, miten laadukasta koulutusta pystytään tarjoamaan tavalla, jolla turhia resursseja ei kulu. Tämä työ kattaa kaiken toiminnan oppilaitoksessa rekrytoinnista ja opetuksen suunnittelusta hallintoon, tiloihin ja kaikkeen muuhun, joka jotenkin liittyy oppilaitoksen arkeen.

Oikeudenmukaisuus on aina tärkeää, kun toimintaa ja tehtäviä suunnitellaan, mutta erityisen tärkeää silloin, kun resurssit ovat niukkoja. Rahoittajalla on suuri työsarka saada rahoitus vastaamaan näihin muuttuviin tarpeisiin.

\section{ERI KOHDERYHMILLÄ ON ERI TARPEET}

Kentän tarpeiden ja kehitysehdotusten kuuleminen esimerkiksi lainsäädännön muutoksissa on todella tärkeää. Säännöllisesti kokoontuva yhteistyöryhmä tarjoaa hyvät mahdollisuudet vuoropuheluun kentän toimijoiden ja opetus- ja kulttuuriministeriön virkamiesten välillä. Yhteistyöryhmässä ovat edustettuina kaikki vapaan sivistystyön oppilaitosmuo- 
VAPAAN dot. Työryhmien avulla SIVISTYSTYÖN

KOULUTUS ON

JUURI NIIN

VAPAATA KUIN SE

AINA ON OLLUT. varmistetaan monipuolisen asiantuntemuksen saaminen valmistelutyöhön. Valmisteluun kuuluu myös lausuntomenettely, jossa kuullaan eri tahojen näkemyksiä.

Vapaa sivistystyö on koulutusmuotona siitä ainutlaatuinen, että sen sisällön rakentamista rajaavat hyvin harvat kuvaukset laissa ja koulutuksen järjestämisluvassa. Tämä antaa lähes rajattomat mahdollisuudet rakentaa koulutusta ihmisten tarpeita vastaavaksi. On kuitenkin löydettävä ne kohderyhmät, joille koulutusta rakentaa. Vapaan sivistystyön asiakkaiksi kuuluvat kaiken ikäiset ihmiset melkein vauvasta tai ainakin lapsesta vaariin.

Jokaisella ikäluokalla on omat tarpeensa ja mieltymyksensä ja niiden tutkiminen ja tiedostaminen on erittäin tärkeää. Myös kaikenlainen vuoropuhelu ja palautteen pyytäminen on olennaista, kun lähdetään etsimään eri kohderyhmille sopivia koulutussisältöjä.

Kilpailevia koulutusmuotoja on paljon. Vapaan sivistystyön koulutuksesta pitäisi pystyä rakentamaan niin kiinnostava, että se myös maksullisena houkuttelee tilanteessa, jossa moni muu koulutus voi olla ilmaista. Väestön ikäkehityksen myötä yhteiskunnassamme on yhä enemmän ihmisiä "parhaassa iässään". Vapaan sivistystyön pitäisi pystyä kohtaamaan heidän tietoisia tai tiedostamattomia tarpeitaan.

Tehokkuutta ja kovaa tahtia vaativa työelämä on luonut nykysukupolvelle erilaisia tarpeita itsensä kehittämiseen. Samalla ihmiset ovat vaurastuneet ja haluavat panostaa itseensä myös taloudellisesti, jos löytävät mielekästä koulutusta. Lisäksi työelämän taakseen jättäneet ihmiset ovat kasvava ryhmä yhteiskunnassamme. He hakevat mahdollisuuksia kehittymiseen, henkiseen hyvinvointiin ja oppimisen iloon koulutuksen keinoin.

\section{VAPAA SIVISTYSTYÖ ON YHÄ VAPAATA}

Monelle on tärkeää pystyä osoittamaan, mitä elämän eri vaiheissa on oppinut, jotta pystyy hyödyntämään opitun täysimäääisesti myöhemmin. Dokumentaatio onkin tullut koulutusmaailmaan ilmiönä, johon oppilaitosten pitäisi pystyä vastaamaan. Näin ne pystyvät paremmin täyttämään asiakkaidensa odotukset.

Vapaan sivistystyön koulutuksessa muutos on kenties vielä suurempi kuin muissa koulutusmuodoissa, koska kirjallisesta dokumentaatiosta on lainsäädännössä hyvin vähän säädöksiä. On kuitenkin tärkeää, että vapaan sivistystyön oppilaitokset pysyvät mukana kehityksessä, sillä opiskelijoille dokumentaatio antaa tärkeää lisäarvoa.

Esimerkiksi koulutusten ja kurssien sisältöjen dokumentoiminen muotoon, joka antaa tietoa ja helpottaa aikaisemmin hankitun osaamisen tunnistamista ja tunnustamista vie aikaa. Se kuitenkin palkitsee tyytyväisinä opiskelijoina ja yhteistyökumppaneina. On toki muistettava että dokumentaatio ei muuta vapaan sivistystyön koulutuksen vapautta miksikään. Kyseessä on vain kirjallinen kuvaaminen asiakkaiden tarpeiden mukaisesti.

Vapaan sivistystyön koulutus on sisältömahdollisuuksineen juuri niin vapaata kuin se aina on ollut. Lopulliset rajat sisällölle asettavat koulutuksen järjestäjät sekä koulutusta suunnittelevien ja toteutettavien henkilöiden osaaminen ja mielikuvitus.

Vapaus on kuitenkin aina yhdistynyt vastuuseen. Vastuu tarkoittaa tässä tapauksessa koulutuksen raameja. Niiden tulee täyttää lain ja asetuksen asettamat vaatimukset.

Vaatimukset kohdistuvat vain pienessä määrin koulutuksessa opittavaan sisältöön. Suurimmaksi osaksi ne kohdistuvat ylläpitäjän ja oppilaitoksen ammattitaitoon suunnitella ja toteuttaa koulutusta siten, että lainsäädännössä olevat reunaehdot täyttyvät.

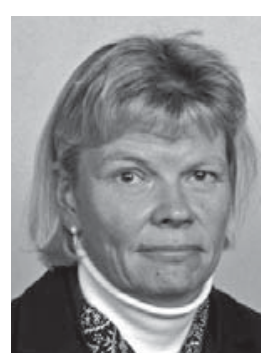

Annika Bussman

Opetusneuvos

Opetus- ja kulttuuriministeriö 